\title{
Students' Readiness to Succeed and Persist in Their University Study
}

\author{
Ali Zuhdi Shaqour ${ }^{1, *}$, Soheil Salha ${ }^{1}$, Assad Tafal ${ }^{2}$, Hiba Shtaya $^{1}$ \\ ${ }^{1}$ Department of Teaching Methods, An-Najah National University, Palestine \\ ${ }^{2}$ Department of Sociology, An-Najah National University, Palestine
}

Received September 9, 2020; Revised October 26, 2020; Accepted November 11, 2020

\begin{abstract}
Cite This Paper in the following Citation Styles
(a): [1] Ali Zuhdi Shaqour, Soheil Salha, Assad Tafal, Hiba Shtaya, "Students' Readiness to Succeed and Persist in Their University Study," Universal Journal of Educational Research, Vol. 8, No. 12, pp. 6907 - 6918 2020. DOI: 10.13189/ujer.2020.081257.
\end{abstract}

(b): Ali Zuhdi Shaqour, Soheil Salha, Assad Tafal, Hiba Shtaya (2020). Students' Readiness to Succeed and Persist in Their University Study. Universal Journal of Educational Research, 8(12), 6907 - $6918 . \quad$ DOI: 10.13189/ujer.2020.081257.

Copyright $\bigcirc 2020$ by authors, all rights reserved. Authors agree that this article remains permanently open access under the terms of the Creative Commons Attribution License 4.0 International License

\begin{abstract}
The higher education institutions in Palestine depend deeply on the rate of students' enrolment. The budget of these institutions depends on the rate of students' enrolment for this reason the institutions always trying to encourage students to enroll in their programs. Therefore, the purpose of the current study is to investigate first year students' perceptions concerning their readiness to succeed and persist in their university study. Mixed qualitative and quantitative approach was used to achieve the purpose of the study. The participants of the study were 776 students from a large university located in the northern of Palestine. Statistical analysis by using the SPSS package was used for analysing quantitative data from the survey. For qualitative data analysis, thematic analysis was used for analysing students' responses on the open-ended questions. The findings of the study revealed that student's friends have a positive influence on students' enrolment at the university. On the other hand, gender and family encouragement did not have any impact on student's pursuing higher education. The study suggested to implement orientation sessions in high schools to provide students more information about the university life from different aspects such as academic, social, and involvement in the activities on campus. The decision-makers in the higher education institutions in Palestine design workshops and programs to encourage students to register at universities.
\end{abstract}

Keywords Higher Education, Readiness, Mixed Methods, Students' Persist

\section{Introduction}

Higher education institutions play a pivotal and influential role in the development and progress of individuals and the community as well as leading the development and sustainability. The role of these institutions is affecting all the key players of a society (Ferrer-Balas et al., 2008; Khan, 2016). Higher education institutions prepare most of the professionals who develop, lead, manage, teach, work in, and influence society's institutions, including the most basic foundation of $\mathrm{K}-12$ education (Cortese, 2003), as educational attainment and completion of higher education institutions' graduates are positively related to productivity, labour market outcomes, and economic growth (Khan, 2016). Baum and Payea, (2013) pointed out that individuals who complete a higher education program acquire significant personal/social benefits, including higher cognitive skills, the ability to concentrate on job-related tasks, and the desire to give back and participate in community service activities. For this crucial role, higher education institutions work hard to provide their students a high-quality education environment that ensures quality graduates. These efforts require students to be ready to learn in order to succeed and endure their real-life skills. The main demand is that learning environment which make students feel that higher education is an important part of their lives and that it is 
worthwhile to stay enrolled [11]. According to [12], universities in all countries are under increasing pressure to improve retention rates for students, especially between the first and second year of the program. This requires a concerted effort on the part of the institution in bringing together the different student support services to address student attrition is needed ([22]; [3]).

The higher education institutions in Palestine depend deeply on the rate of students' enrolment. The budget of these institutions depends on the rate of students' enrolment for this reason the institutions always trying to encourage students to enroll in their programs. Universities established different services in order to increase student's readiness to involve in the university life. Many students transfer from a program to another one after the first semester. These changes are due to the student's preparation process in the K-12 stage. In addition, literature concerning university students' readiness to success and persist in Arab context is rarely found. More research is needed to unpack the potential of preparing these students to transfer to a higher education college stage.

Consequently, the purpose of this study is to explore students' readiness to success and continue in their first year's university study. Analysis of students' perspectives of college readiness comprised ten themes organized into three categories which were skills and abilities, background about the influential factors to join higher education, and self-concept of the institutional culture [4]. The interrelationship between these categories form the context of current mixed qualitative and quantitative study ([19]; [20]), as a support network for ANNU students' readiness. Specifically, the study examines a) differences in college readiness skills and abilities among students to persist at university, b) factors influencing persistence in terms of life experience, and c) students Self-Concept to persist. In addition to these categories, several educators' thoughts regarding students' university readiness like [19], [11], and [25] informed this study especially in designing its survey instrument which included open-ended questions. Student demographics including background, socio-economic, and self-concept patterns were analysed through descriptive statistics.

Current study attempted to examine the status of first year students that could affect their readiness to success and persist in their university study. This examination was achieved through dealing with different factors such as university life and learning environment, students' backgrounds, and social influences.

Educators presented different perspectives, models and theories related to students' readiness and their academic success. Astin (1985) presented his involvement theory, while other scholars developed critical theory (Freire, 1970, 1992; Horkheimer, 1982; McClaren \& Hammer, 1989). Tinto, who introduced academic integration theory in 1975, claimed that when students enroll to university, they bring with them personal attributes, academic ability, and other socio-cultural characteristics [2].

Revealing the factors that influence students' readiness to be engaged in the higher education institution could help the decision-maker in the institutions to be aware about these factors and can develop programs to capacity building of the freshmen students and to prepare them for the university life. Moreover, the decision-makers in the Ministry of Education and the higher education institutions could collaborate together to prepare high school students to the university life based on the findings of the present study.

\section{Literature Review}

The researchers used the Unified Theory of Acceptance and Use of Technology (UTAUT) developed by Venkatesh and colleagues (2003). The framework helped the researchers to develop the study tool and data analysis. Many researchers used the UTAUT framework in studying technology acceptance in higher education and public schools ([28]; [29]). Previous research mentioned that UTAUT predicted $70 \%$ of acceptance technology ([28]; [29]; [30]).

[7] stated that the empirical literature has identified various factors such as characteristics of the university, campus environment, background of the students (e.g., academic preparation and motivation), perceptions of mattering to school, building social capital, and studentfaculty interaction as key components of student success. The hard truth is that success in college is strongly related to precollege academic preparation and achievement as well as other factors such as family income and parents' education ([14]; [16]). [15] stated that students' satisfaction with and success in college are affected by many factors which they bring with them, such as high school achievement, ethnicity, gender, and age. So, readiness for education is a key indicator of students' satisfaction of university life which leads to persistence, receptivity and success.

[5] defined readiness as the level of preparation a student needs in order to enroll and succeed, without remediation in a credit-bearing programme at a higher education institution. This readiness according to him includes inter-related cognitive strategies, acquiring content knowledge, academic behaviors, and contextual knowledge and skills. So, determining students' readiness for university education is seen as the first step in understanding the students that enroll at an institution ([4]). [11] related positive student outcomes in their programs with one or more of four mechanisms which are creating social relationships, clarifying aspirations and enhancing commitment, developing college know-how, and making college life feasible.

Students in all types of postsecondary institutions are likely to encounter difficulties in understanding and 
enacting college expectations [11]. College students in their first year are usually characterized with instability and uncertainty as they have to adjust to the new institutional environment as well as manage increased levels of stress ([4]; [5]; [6]). The major theorists of student persistence according to [11] argue that this persistence is influenced by a combination of pre-existing characteristics, external forces, and institutional factors. Students' persistence in college as reported by [15] is related to a complex set of factors, including student involvement, ethnicity, gender, and age, as well as place of residence of the student. [25] illustrated two reasons why more high school graduates are not ready for college namely; academic such as the disconnect between what high school teachers teach and what postsecondary instructors expect with regard to students' preparation for first-year credit-bearing courses, schools are able to control this reason, and non-academic reasons such as family variables and peer influences outside of school which schools are unable to control them.

[21] suggested attitude-behaviour i.e. personality traits such as self-efficacy, self-concept and internal locus of control, to emphasize the importance of students' characteristics to success in college. [28] study added other factors associated with readiness, namely; skills in time-management, motivational factors, background factors and student self-concept, in addition to academic achievement (Byrd \& MacDonald, 2005). These educator's work indicated that students' readiness was associated with different factors including academic, socioeconomic and personal ones.

\section{The Emergence of Higher Education in Palestine}

The historical roots of the Palestinian higher education system date back to the 1940 s, when a relatively large number of students began to attend higher education institutions abroad, where there were no institutions within Palestine, and the main orientation of students was then for Egyptian, American and British universities, and of course, the costs of studying at that time were relatively high and the contacts needed to obtain admission were difficult and not accessible to everyone, so higher education was largely limited to the children of well-off families of social and political status. Higher education institutions grew up mostly under Israeli occupation and with national local initiatives and grew rapidly until the number of licensed higher education institutions in the West Bank and Gaza Strip in the academic year (2018-2019) reached 50 universities, colleges and universities. Two of these universities are universities-based open learning. More than 214,000 students are enrolled in these universities, including about 6,600 students in master's programs, and about 65,000 open education students, all in specialties of approximately $(1,000)$ specializations and academic programs, according to the Higher Education Database ([31]; [32]).

\section{The Reality of Higher Education in Palestine}

The philosophy and objectives of higher education are based mainly on contributing to the development of society and meeting its requirements and needs (Mahajan, 2020). Higher education is the main source of training of skills and competencies in the human resource, as the most important resource for development [1], but the reality of the Palestinian situation indicates the inability of higher education to achieve the desired goals at this level, where field data confirm a state of divergence between university graduates and the Palestinian labor market [9].

\section{The Challenges Facing Higher Education in Palestine}

The higher education sector in Palestine suffers from multiple crises, most notably the chronic financial crisis on the one hand, and the level of graduates who experience a high rate of unemployment on the other, so it is necessary to highlight the most important of these problems and ways of solving them, as follows:

\section{Funding challenges}

Annual university budgets of about $\$ 80$ million, tuition fees are the main source of funding, as well as assistance from the Higher Education Council. The delay in the disbursement of university allocations leads to a permanent shortfall in university expenses, estimated at \$25 million, and the causes of the university's financial crisis are due to several reasons, including: - the recent suspension of external (European) financial support. Universities do not receive their allocations from the budgets of the National Authority. Low hourly rate (insufficient university tuition). Accumulated fiscal deficit for consecutive years. The number of student exemptions from tuition fees is high. The lack of investments and self-returns for the university [10].

\section{Challenges related to scientific research}

The higher education institutions in Palestine are confronting many obstacles in scientific research. Most of these challenges related to the unique case of Palestine which is under occupation and a lot of restriction on the Palestinian daily life activities including academic one ([12]; [23]). Previous studies in terms of higher education in the Palestinian universities revealed different reasons for the obstacles to scientific research in Palestinian universities are concentrated in several reasons ([1]; [10]; 
[12]):

First: Information reasons:

- The lack of specialized journals and magazines

- The lack of a modern information and technology network in libraries.

- The Lack of coordination between libraries and the university to provide the necessary resources for research.

Second: Reasons related to the management practices of universities:

- The lack of budgets for scientific research.

- The absence of material and moral incentives that encourage scientific research.

- Universities are not open to local and international institutions to support scientific research

Third: Reasons related to publishing:

- The failure to activate the copyright law in Palestine.

- Poor procedures for follow-up arbitration and publication of the pillars of scientific research in universities. Fourth: Reasons related to faculty:

- The lack of skill of scientific research. The faculty member is concerned about the teaching burdens he has on himself.

- The lack of motivation on the part of the faculty member due to the lack of publishing and literary appreciation

\section{Challenges for faculty members:}

- The status of the university's faculty member depends on the nature of the personal relationships that bind him to the university administration and not on his ability to teach well.

- The different criteria and standards between universities in promoting the faculty members and linking the literary appreciation of the university professor to his party affiliation.

- Ignoring the role of scientific research as a criterion for the promotion of faculty.

- The lack of professional development centers within the university to develop the competence of the faculty member.

\section{Ways to develop higher education in Palestine:}

- Including higher education support as a priority in the government budget.

- Activating the Higher Education Council

- Third: the creation of endowments.

- The development of the vocational and technical education system.

- Strengthening the partnership between the private and public sectors.

- Allocating a budget for scientific research in universities.

- $\quad$ Raising the level of networking between universities and their graduates after graduation.

\section{Research Questions}

In order to answer the above-mentioned problem statement focusing on the factors affecting students' successes and persist in university, the present study explores the following questions:

- What was the role, if any, of family and guidance on students' readiness to join university?

- What are the students' perceptions on the conditions that support their readiness to succeed in university during school study and during their first-year university study?

\section{Research Design}

The researchers used a mixed-methods approach as a research design. A survey was developed based on the findings of previous studies. The survey is composed of two parts. The first part is closed questions 45 items (yes and no questions). The second part was open-ended questions which were considered as a qualitative part of the study.

\section{Quantitative approach}

The higher education institutions in Palestine are similar in their teaching procedures except the open education institutions. Therefore, the researchers selected a large university in the north of Palestine to implement the study. The university is considered to be representative the higher education since this context is similar as we mentioned early. In order to expand existing research, a survey with open-ended questions was implemented to investigate the university students' readiness to study and success in the first year of their academic. This implementation gave researchers the opportunity to investigate these students' readiness and the factors that affect this readiness, and as such, contribute to the existing literature. Due to the importance of gathering information about these factors, an explorative study was obtained. This study has the purpose to investigate the influences which affect students' readiness for university study and success. In this case, an explorative study was appropriate.

\section{Qualitative approach}

Students' responses on the open-ended questions were collected and organized in a word sheet. The researchers used thematic analysis to analyse the qualitative data through reading the text many times. Researchers worked individually on qualitative analysis. After finishing the data analysis, the researchers meet to discuss the categories of the qualitative and calculated the agreement among the researchers on the categories. The agreement among the researchers in coding the themes was $89 \%$. 
The researchers conducted a triangulation of the findings of the qualitative data analysis with the quantitative findings.

\section{Population of the study}

The population of this study consisted of all freshmen students at An- Najah University. The total number of them is 4,200 students according to the Deanship of registration and Admission at the university.

\section{Demographic information of the sample}

The sample of the study consists of (776) students was chosen as a stratified random sample from the whole population according to three variables: gender, place of residence and college. The distribution of the sample based on gender is presented in the table 1. Whereas the distribution of the sample based on the place of residence is illustrated in table 2. Moreover, the sample distribution based on the college is presented in table 3 . Table 4 presented students' responses to the role of the economic status of your family in selecting your specialization. Students' responses to the family encouragement to be enrolled at the university were presented in table 5. Also, students' responses to the role of their family in selecting your specialization presented in table 6. And their responses to the role of friends in your university readiness presented in table 7 .

Table 1. Distribution of sample according to Gender

\begin{tabular}{ccc}
\hline Gender & Frequency & Percentage \\
\hline Male & 184 & 23.7 \\
Female & 592 & 76.3 \\
Total & 776 & 100.0 \\
\hline
\end{tabular}

Table 2. Distribution of sample according to Place of residence

\begin{tabular}{ccc}
\hline Place of residence & Frequency & Percentage \\
\hline City & 364 & 46.9 \\
Village & 392 & 50.5 \\
Camp & 20 & 2.6 \\
Total & 776 & 100.0 \\
\hline
\end{tabular}

Table 3. Distribution of sample according to College

\begin{tabular}{ccc}
\hline College & Frequency & Percentage \\
\hline Scientific & 402 & 51.8 \\
Humanities & 374 & 48.2 \\
Total & 776 & 100.0 \\
\hline
\end{tabular}

\section{Study results:}

Table 4. Students' responses to the role of the economic status of your family in selecting your specialization

\begin{tabular}{ccc}
\hline $\begin{array}{c}\text { The role of } \\
\text { economic status }\end{array}$ & Frequency & Percentage \\
\hline Yes & 204 & 26.3 \\
No & 572 & 73.7 \\
Total & 776 & 100.0 \\
\hline
\end{tabular}

Table 5. Students' responses to the family encouragement to be enrolled at the university

\begin{tabular}{ccc}
\hline $\begin{array}{c}\text { The family } \\
\text { encouragement }\end{array}$ & Frequency & Percentage \\
\hline Yes & 723 & 93.2 \\
No & 53 & 6.8 \\
Total & 776 & 100.0 \\
\hline
\end{tabular}

Table 6. Students' responses to the role of their family in selecting your specialization

\begin{tabular}{ccc}
\hline The role of family & Frequency & Percentage \\
\hline Yes & 325 & 41.9 \\
No & 451 & 58.1 \\
Total & 776 & 100.0 \\
\hline
\end{tabular}

Table 7. Students' responses to the role of friends in your university readiness

\begin{tabular}{ccc}
\hline The role of family & Frequency & Percentage \\
\hline Yes & 232 & 29.9 \\
No & 544 & 70.1 \\
Total & 776 & 100.0 \\
\hline
\end{tabular}

Hypothesis 1:

There is no significant relation at $(\alpha=0.05)$ between the role of the economic status of students family in selecting the specialization and gender.

The researchers used Chi square test to examine hypothesis 1 . Table 8 shows the results

Table 8. Chi square test to examine the relation between the role of the economic status and gender

\begin{tabular}{cccccc}
\hline $\begin{array}{c}\text { Gender } \\
\text { Economic } \\
\text { status }\end{array}$ & Male & Female & D.F & Chi-Sq. & Sig. \\
\cline { 2 - 6 } Yes & 62 & 142 & 1 & 6.829 & $0.009^{*}$ \\
No & 122 & 450 & & & \\
\hline
\end{tabular}

Table 8 showed there is significant relation at $(\alpha=0.05)$ between the role of the economic status of students family in selecting the specialization and gender. 
Hypothesis 2:

There is no significant relation at $(\alpha=0.05)$ between the family encouragement to be enrolled at the university and gender.

The researchers used Chi square test to examine hypothesis 2 . Table 8 shows the results

Table 9. Chi square test to examine the relation between the family encouragement and gender

\begin{tabular}{cccccc}
\hline \multirow{2}{*}{$\begin{array}{c}\text { Gender } \\
\text { family } \\
\text { encouragement } \\
\text { Yes }\end{array}$} & Male & Female & D.F & Chi-Sq. & Sig. \\
\cline { 2 - 6 } No & 171 & 552 & 1 & 0.021 & 0.885 \\
\hline
\end{tabular}

Table 9 showed there is no significant relation at $(\alpha=0.05)$ between the family encouragement to be enrolled at the university and gender.

Hypothesis 3:

There is no significant relation at $(\alpha=0.05)$ between the role of the family in selecting the students' specialization and gender.

The researchers used Chi square test to examine hypothesis 3 . Table 10 shows the results

Table 10. Chi square test to examine the relation between the family role and gender

\begin{tabular}{cccccc}
\hline $\begin{array}{c}\text { Gender } \\
\text { family role }\end{array}$ & Male & Female & D.F & Chi-Sq. & Sig. \\
\cline { 2 - 6 } Yes & 68 & 257 & 1 & 2.403 & 0.121 \\
No & 116 & 335 & & & \\
\hline
\end{tabular}

Table 10 showed there is no significant relation at $(\alpha=0.05)$ between the role of the family in selecting the student specialization and gender.

Hypothesis 4:

There is no significant relation at $(\alpha=0.05)$ between the role of the economic status of student's family in selecting the specialization and place of residence.

The researchers used Chi square test to examine hypothesis 4 . Table 11 shows the results

Table 11. Chi square test to examine the relation between the role of the economic status and place of residence

\begin{tabular}{ccccccc}
\hline $\begin{array}{c}\text { Place of } \\
\text { residence } \\
\begin{array}{c}\text { Economic } \\
\text { status } \\
\text { Yes }\end{array}\end{array}$ & City & Village & Camp & D.F & Chi-Sq. & Sig. \\
\cline { 2 - 7 } No & 90 & 108 & 6 & 2 & 0.924 & 0.630 \\
\hline
\end{tabular}

Table 11 showed there is no significant relation at $(\alpha=0.05)$ between the role of the economic status of students family in selecting the specialization and place of residence.

\section{Hypothesis 5:}

There is no significant relation at $(\alpha=0.05)$ between the family encouragement to be enrolled at the university and place of residence.

The researchers used Chi square test to examine hypothesis 5 . Table 12 shows the results

Table 12. Chi square test to examine the relation between the family encouragement and place of residence

\begin{tabular}{ccccccc}
\hline $\begin{array}{c}\text { Place of } \\
\text { residence } \\
\text { family } \\
\text { encouragement } \\
\text { Yes }\end{array}$ & City & Village & Camp & D.F & Chi-Sq. & Sig. \\
\cline { 2 - 7 } No & 327 & 376 & 20 & 2 & 12.481 & $0.002 *$ \\
\hline
\end{tabular}

Table 12 showed there is significant relation at $(\alpha=0.05)$ between the family encouragement to be enrolled at the university and place of residence.

Hypothesis 6:

There is no significant relation at $(\alpha=0.05)$ between the role of the family in selecting the student specialization and place of residence.

The researchers used Chi square test to examine hypothesis 6 . Table 13 shows the results

Table 13. Chi square test to examine the relation between the family role and place of residence

\begin{tabular}{ccccccc}
\hline $\begin{array}{c}\text { Place of } \\
\text { residence } \\
\text { family role }\end{array}$ & City & Village & Camp & D.F & Chi-Sq. & Sig. \\
\cline { 2 - 7 } Yes & 140 & 173 & 12 & 2 & 5.263 & 0.072 \\
No & 224 & 219 & 8 & & & \\
\hline
\end{tabular}

Table 13 showed there is no significant relation at $(\alpha=0.05)$ between the role of the family in selecting the student specialization and place of residence.

\section{Hypothesis 7:}

There is no significant relation at $(\alpha=0.05)$ between the role of the economic status of students' family in selecting the specialization and college.

The researchers used Chi square test to examine hypothesis 7 . Table 14 shows the results

Table 14. Chi square test to examine the relation between the role of the economic status and college

\begin{tabular}{cccccc}
\hline College & & & & & \\
$\begin{array}{c}\text { Economic } \\
\text { status }\end{array}$ & Scientific & Humanities & D.F & Chi-Sq. & Sig. \\
\cline { 2 - 5 } Yes & 134 & 70 & 1 & 21.362 & $0.00001^{*}$ \\
No & 268 & 304 & & & \\
\hline
\end{tabular}

Table 14 showed there is significant relation at $(\alpha=0.05)$ between the role of the economic status of students family in selecting the specialization and college.

\section{Hypothesis 8:}

There is no significant relation at $(\alpha=0.05)$ between the family encouragement to be enrolled at the university and 
college.

The researchers used Chi square test to examine hypothesis 8 . Table 15 shows the results

Table 15. Chi square test to examine the relation between the family encouragement and college

\begin{tabular}{cccccc}
\hline \multirow{2}{*}{$\begin{array}{c}\text { College } \\
\text { family } \\
\text { encouragement }\end{array}$} & Scientific & Humanities & D.F & Chi-Sq. & Sig. \\
\cline { 2 - 6 } Yes & 367 & 356 & 1 & 4.616 & $0.022^{*}$ \\
No & 35 & 18 & & & \\
\hline
\end{tabular}

Table 15 showed there is significant relation at $(\alpha=0.05)$ between the family encouragement to be enrolled at the university and college.

\section{Hypothesis 9:}

There is no significant relation at $(\alpha=0.05)$ between the role of the family in selecting the student specialization and college.

The researchers used Chi square test to examine hypothesis 9 . Table 16 shows the results

Table 16. Chi square test to examine the relation between the family role and college

\begin{tabular}{cccccc}
\hline $\begin{array}{c}\text { College } \\
\text { family } \\
\text { role }\end{array}$ & Scientific & Humanities & D.F & Chi-Sq. & Sig. \\
\cline { 2 - 6 } Yes & 167 & 158 & 1 & 0.039 & 0.450 \\
No & 235 & 216 & & & \\
\hline
\end{tabular}

Table 16 showed there is no significant relation at $(\alpha=0.05)$ between the role of the family in selecting the student specialization and college.

Hypothesis 10:

There is no significant relation at $(\alpha=0.05)$ between students' guidance and gender.

The researchers used Chi square test to examine hypothesis 10 . Table 17 shows the results

Table 17. Chi square test to examine the relation between guidance and gender

\begin{tabular}{cccccc}
\hline $\begin{array}{c}\text { Gender } \\
\text { Guidance }\end{array}$ & Male & Female & D.F & Chi-Sq. & Sig. \\
\cline { 2 - 6 } Yes & 13 & 23 & 1 & 3.373 & 0.066 \\
No & 79 & 273 & & & \\
\hline
\end{tabular}

Table 17 showed there is no significant relation at $(\alpha=0.05)$ between the student guidance and gender.

\section{Hypothesis 11:}

There is no significant relation at $(\alpha=0.05)$ between students' guidance and college.

The researchers used Chi square test to examine hypothesis 11 . Table 18 shows the results
Table 18. Chi square test to examine the relation between guidance and college

\begin{tabular}{cccccc}
\hline $\begin{array}{c}\text { College } \\
\text { Guidance }\end{array}$ & Scientific & Humanities & D.F & Chi-Sq. & Sig. \\
\cline { 2 - 6 } Yes & 23 & 13 & 1 & 2.321 & 0.128 \\
No & 178 & 174 & & & \\
\hline
\end{tabular}

Table 18 showed there is no significant relation at $(\alpha=0.05)$ between the student guidance and college.

Hypothesis 12:

There is no significant relation at $(\alpha=0.05)$ between the role of guidance and gender.

The researchers used Chi square test to examine hypothesis 12 . Table 19 shows the results

Table 19. Chi square test to examine the relation between the role of guidance and gender

\begin{tabular}{cccccc}
\hline $\begin{array}{c}\text { Gender } \\
\text { Role of } \\
\text { guidance } \\
\text { Yes }\end{array}$ & Male & Female & D.F & Chi-Sq. & Sig. \\
\cline { 2 - 5 } No & 58 & 162 & 1 & 5.065 & $0.024^{*}$ \\
\hline
\end{tabular}

Table 19 showed there is significant relation at $(\alpha=0.05)$ between the role of guidance and gender.

Hypothesis 13:

There is no significant relation at $(\alpha=0.05)$ between the role of guidance and college.

The researchers used Chi square test to examine hypothesis 13 . Table 20 shows the results

Table 20. Chi square test to examine the relation between the role of guidance and gender

\begin{tabular}{cccccc}
\hline $\begin{array}{c}\text { college } \\
\text { Role of } \\
\text { guidance }\end{array}$ & Scientific & Humanities & D.F & Chi-Sq. & Sig. \\
\cline { 2 - 6 } Yes & 99 & 101 & 1 & 0.878 & 0.202 \\
No & 102 & 86 & & & \\
\hline
\end{tabular}

Table 20 showed there is significant relation at $(\alpha=0.05)$ between the role of guidance and college.

\section{Hypothesis 14:}

There is no significant relation at $(\alpha=0.05)$ between students' social adjustment and gender.

The researchers used Chi square test to examine hypothesis 14 . Table 21 shows the results

Table 21. Chi square test to examine the relation between students' social adjustment and gender

\begin{tabular}{cccccc}
\hline $\begin{array}{c}\text { Gender } \\
\text { Social } \\
\text { adjustment }\end{array}$ & Male & Female & D.F & Chi-Sq. & Sig. \\
\cline { 2 - 6 } Yes & 46 & 137 & 1 & 0.389 & 0.307 \\
No & 46 & 159 & & & \\
\hline
\end{tabular}


Table 21 showed there is no significant relation at $(\alpha=0.05)$ between the students' social adjustment and gender.

\section{Hypothesis 15:}

There is no significant relation at $(\alpha=0.05)$ between students' social adjustment and college.

The researchers used Chi square test to examine hypothesis 15 . Table 22 shows the results

Table 22. Chi square test to examine the relation between students' social adjustment and college

\begin{tabular}{cccccc}
\hline College & & & & & \\
$\begin{array}{c}\text { Social } \\
\text { adjustment }\end{array}$ & Scientific & Humanities & D.F & Chi-Sq. & Sig. \\
\cline { 2 - 5 } Yes & 90 & 91 & 1 & 0.599 & 0.477 \\
No & 110 & 95 & & & \\
\hline
\end{tabular}

Table 22 showed there is no significant relation at $(\alpha=0.05)$ between the students' social adjustment and gender.

\section{Summarizing the Quantitative Findings}

Due the nature of the items of the survey, Chi square test was used in the quantitative data analysis. Data analysis revealed that gender has no effect on selecting the specialization in the university as well as the family economic situation of the student. There is no significant relation at $(\alpha=0.05)$ between students' guidance and gender in the study among the participants. However, in many studies, the economic situation has crucial role in choosing the specialization in the higher education level. Furthermore, there was a significant role between the between the role of guidance and the student's college. Moreover, we did not find a significant relation at $(\alpha=0.05)$ between the family encouragement and student's enrolment at the university or the college.

Based on the first research question regarding the role of family and guidance on student's readiness to join the university, the findings of the study showed that family encouragement does not have role on students' enrolment in the university. In addition the family does not have a role in student specialization in higher education. In terms of the role of guidance, there is no relation between it and the students' registration in the college but we found a role between the guidance and gender. Moreover we did not find a relation between students' social adjustment and gender, as well as with students' registration in the college.

\section{Qualitative Analysis}

In order to answer the second research question to explore students' perceptions about the conditions that support their readiness in the first year in the university, the Participants' answers of the open ended questions emanated the qualitative data of current study. These answers were analysed according to their three themes namely; background factors, college readiness skills and abilities, and Non-traditional Student Self-Concept, and then coded and enumerating the frequency of themes within a sample, the percentage of themes associated with a given category of respondent [19]. This approach provided researchers with deep understanding of the case under investigation as "qualitative codes are multidimensional, meaning they can and do provide insights into a host of interrelated conceptual themes or issues during analysis" ([11]: cited in [8]).

The following is the analysis of the themes:

\section{- Background Factors}

The role of family and friends in choosing study program:

$19 \%$ of the sample of the study indicated that their families and friends played the role encouragement in choosing their study programs. $67 \%$ of the sample of the study indicated that the role of family and friends was very important in terms of providing assistance on the nature of study at the university and the programs. While $12 \%$ of the sample of the study indicated that the role of friends and family was in their role in clarifying the future of the programs' graduates. The Role of Friends in Joining the University:

$24.1 \%$ of the sample of the study's role in joining the University was positive and encouragement. While $35.4 \%$ of the study sample indicated that their role was in describing the word of university, its free life, freedom of expression, and maturity. $40.5 \%$ of the study sample showed their readiness to assist in joining the university.

Psychological and social readiness to join university:

The sample of the study mentioned different types of difficulties they faced during joining university; $45.5 \%$ of the sample showed the low level of English as a problem, while $27 \%$ of the sample indicated the problem of adjustment i.e. moving from school to university, and $27.6 \%$ of respondents mentioned the lack of adequate guidance and assistance as difficulties when joining university.

The main reason for going to university:

$13.9 \%$ of the sample indicated that the reason is to gain experience about the community and increase the chance of better life. While $44.5 \%$ of the sample indicated that it is a norm to join university after getting school certificate "Injaz". $10.2 \%$ of respondents indicated that the main reason to join university is to get a future job and to help oneself and the family. $1.5 \%$ of the respondents indicated that they liked the university programs. The reason is the student's love for specialization and his desire to study and work in his field. Also, $19.3 \%$ of the sample of the study indicated that the reason of joining university was parents 
beliefs of better future for their children. $10.6 \%$ of the sample of the study showed that the reason of joining university was get a university degree.

\section{Who played the most significant role in joining university?}

$9.4 \%$ of the sample of the study showed that fathers played a vital role in joining university. $10.1 \%$ indicated that it was their own decision, while $80.5 \%$ said that the decision was of the whole family.

\section{- College Readiness Skills and Abilities}

Skills and abilities of college readiness:

Suffering from negative societal perception of some university programs before choosing a university discipline $29.3 \%$ of respondents indicated that the negative societal perception of some programs i.e. as not economically feasible in the distant future, while $35 \%$ indicated that the negative societal perception of some programs was due to the low level of tawjihi "Injaz. $35.8 \%$ of the study sample showed that the negative societal view of some programs because they do not have any value and is allocated only to students with low levels of tawjihi "Injaz".

Reasons for feeling alienated at the beginning of joining university:

With regard to the feeling of alienation at the beginning of joining the university, the reasons were $53.8 \%$ in the difficulty of adapting to the program of study. While $46.2 \%$ showed that the alienated feeling came from the belief of the uselessness of the program of study.

The main reasons behind the adjustment and acclimation of the university students during the first year of enrolment.

As for the main reasons behind the difficulty of students' adjustment and acclimation during the first year of his enrolment in the university, the study sample indicated that $17.5 \%$ of the sample showed that the reason behind the feeling of alienation is due to the lack of awareness of university roles $66.9 \%$ of the sample indicated that the main reasons for feeling alienated was that the transition from an incubating environment to a new environment in which the student does not have any friendships or acquaintances, while $15.6 \%$ of the sample indicated that the main reasons for feeling alienated was that the feeling of shock As a result of the changing learning environment and social environment from school to university. $10.8 \%$ of the sample of the study showed that the student's success in adaptation at the university is due to the study program which mainly reflects the student's personal desire and tendencies and their love of joining the program. Incubator through forming friendships with students and building good relations with faculty members and adapt to them, as $8.4 \%$ indicated that the reason is due to the students' personality and commitment to their role and the dates of lectures and exams. While $4.8 \%$ of respondents showed that the main reason is due to the student's personality and ability and extent Self - confidence plus Family support for the first year of study.

\section{- Non-traditional Student Self-Concept}

$11.5 \%$ of the study sample adjustment was due to the university' help in providing guidance and facilities to connect other communities in university. $55.8 \%$ of the respondents appreciated university efforts for social and academic adjustment, through conducting activities and delivering lectures and seminars, in addition to orientation meetings. $19.2 \%$ of the respondents indicated the effect of the contribution of their colleges of their self-concept, attitudes, and identity. While $13.5 \%$ of these respondents indicated the role of their teachers in establishing social relations among students.

\section{Discussion}

The purpose of the study was to explore first year students' perceptions towards their readiness to succeed and continue their higher education at the university level. The findings of the study revealed that gender and socio-cultural factors don't have any role on students' enrolment at the university level, which consistent with previous studies such as [10], and [15]. In addition, students' enrolment was affected by friends and guidance from the university orientation sessions which was consistent with [11]. Students' backgrounds and their skills and abilities were important factors that influence students' enrolment in higher education institutions which was congruent with [25]. Families encouragement for students to enroll in the university doesn't have any impact on students, which is consistent with [24].

\section{Limitations of the Study}

The current study has two limitations. The first one is related to the design of the study specifically recruiting the participants since it depends on only one university. In addition, the study depended on self-reported tool for data collection. It should have different tool and take the lecturers at the university into consideration. One of the other tools is focus group sessions for students, parents and staff from different universities. Therefore, it is difficult to generalize the findings of the current study to different context inside or outside Palestine. This study has limitations related to the design of the study and the potential for generalization of findings due to sampling methods. An important limitation of this study is the qualitative part which depended on open-ended questions, it should be interviews or document analysis or interviewing with family/parents. 


\section{Implications for Future Research}

The study should be replicated in different context and use different tools for data collection, different contexts, and recruit much participants from different backgrounds as much as. Families/parents should be an important part of a new study about students' readiness to register in a higher education.

\section{Implications of the Findings}

The findings of the recent study could guide the decision-makers in the higher education institutions in Palestine to design workshops and programs to encourage students to register at universities. The relationship officers at the higher education institutions should arrange field trips to the schools and meet the high school students to talk about the life of higher education. In addition, the Ministry of Education should encourage schools to visit the universities in their areas and to have some lectures about campus activities and the services universities provided.

\section{Acknowledgments}

The authors would like to acknowledge An-Najah National University (ANNU) for its financial support to carry out this project (number ANN-1819-Sc002).

\section{REFERENCES}

[1] Affouneh, S., Wimpenny, K., Ghodieh, A. R. F., Alsaud, L. A., \& Obaid, A. A. (2018). Reflection on MOOC Design in Palestine. The International Review of Research in Open and Distributed Learning, 19(2).

[2] Cabrera, A. F., Nora, A., \& Castaneda, M. B. (1993). College persistence: Structural equations modeling test of an integrated model of student retention. The journal of higher education, 64(2), 123-139.

[3] Camargo, E. (2017). Faculty perspectives on diversity and inclusion at a highly diverse institution: A study of organizational culture (Doctoral dissertation, Virginia Tech).

[4] Choy, W. C., \& Lau, P. Y. F. (2019). Cross-border to Taiwan but not China: The decision-making mechanism of Hong Kong students pursuing higher education in Taiwan. Social Transformations in Chinese Societies, 15(1), 21-36.

[5] Conley, D. T. (2007). Redefining College Readiness. Educational Policy Improvement Center (NJ1).

[6] Corbin, J., Strauss, A. L., \& Strauss, A. (2015). Basics of qualitative research. sage.

[7] Demir, M., Burton, S., \& Dunbar, N. (2019). ProfessorStudent Rapport and Perceived Autonomy Support as
Predictors of Course and Student Outcomes. Teaching of Psychology, 46(1), 22-33.

[8] Driscoll, D. L., Appiah-Yeboah, A., Salib, P., \& Rupert, D. J. (2007). Merging qualitative and quantitative data in mixed methods research: How to and why not.

[9] El Talla, S. A., FarajAllah, A., Abu Naser, S. S., \& Al Shobaki, M. J. (2018). The Reality of University Performance According to the Models of Excellence in Palestinian Universities. International Journal of Academic Multidisciplinary Research (IJAMR), 2(10), 62-77.

[10] Isaac, J., Jemmali, H., Fallah, B., Al-Issa, F., Istanbuli, A., Qamar, M. A., \& Al Azzeh, A. (2019). Study of Higher Education and Research in Palestine.

[11] Karp, M. M. (2011). Toward a New Understanding of Non-Academic Student Support: For Mechanisms Encouraging Positive Student Outcomes in the [12] Community College. CCRC Working Paper No. 28. Assessment of Evidence Series. Community College Research Center, Columbia University.

[12] Shraim, K., \&Khlaif, Z. (2010). An e-learning approach to secondary education in Palestine: opportunities and challenges. Information Technology for Development, 16(3), 159-173.

[13] Mahajan, N. (2020). Role of Higher Education in Economic Development (Special Reference of Private University in Lucknow District). Journal of Business Management \& Quality Assurance (e ISSN 2456-9291), 3(2), 43-48.

[14] Portnoi, L. M., \& Kwong, T. M. (2019). Employing resistance and resilience in pursuing K-12 schooling and higher education: Lived experiences of successful female first-generation students of color. Urban Education, 54(3), 430-458.

[15] Peltier, G. L., Laden, R., \& Matranga, M. (2000). Student persistence in college: A review of research. Journal of College Student Retention: Research, Theory \& Practice, 1(4), 357-375.

[16] Kuh G, Kinzie J, Buckley J et al. (2006) What matters to student success: A review of the literature. Commissioned Report: http://nces.ed.gov/IPEDS/research/pdf/Kuh_Team_Report. pdf [accessed Jan 2019].

[17] Nora, A., Barlow, E., \& Crisp, G. (2005). Student persistence and degree attainment beyond the first year in college. College student retention: Formula for success, 129-153.

[18] Miles, M. B., Huberman, A. M., \& Saldana, J. (2014). Qualitative data analysis: A methods sourcebook (3rd ed.). Thousand Oaks, CA: SAGE.

[19] Onwuegbuzie, A. J., \& Leech, N. L. (2005). Taking the "Q" out of research: Teaching research methodology courses without the divide between quantitative and qualitative paradigms. Quality \& Quantity, 39, 267-296.

[20] Powell, H., Mihalas, S., Onwuegbuzie, A. J., Suldo, S., \& Daley, C. E. (2008). Mixed methods research in school psychology: A mixed methods investigation of trends in the literature. Psychology in the Schools, 45, 291-309.

[21] Patton, M. Q. (2005). Qualitative research. Encyclopaedia of 
statistics in behavioural science.

[22] John, E. P. S., Daun-Barnett, N., \&Moronski-Chapman, K. M. (2018). Public policy and higher education: Reframing strategies for preparation, access, and college success. Routledge.

[23] Traxler, J., Khaif, Z., Nevill, A., Affouneh, S., Salha, S., Zuhd, A., \&Trayek, F. (2019). Living under occupation: Palestinian teachers' experiences and their digital responses. Research in Learning Technology, 27.

[24] Van Roekel, N. P. D. (2008). Parent, family, community involvement in education. Policy Brief. Washington, DC: National education Association.

[25] Venezia, A., \& Jaeger, L. (2013). Transitions from high school to college. The future of children, 117-136.

[26] Vu, T. L. A., \& Le, T. Q. (2019). Development orientation for higher education training programme of mechanical engineering in industrial revolution 4. 0: a perspective in vietnam. J. Mech. Eng. Res. Dev, 42(1), 68-70.
[27] Zepke, N., \& Leach, L. (2010). Improving student engagement: Ten proposals for action. Active learning in higher education, 11(3), 167-177.

[28] Khlaif, Z. N. (2018). Factors influencing teachers' attitudes toward mobile technology integration in K-12. Technology, Knowledge and Learning, 23(1), 161-175.

[29] Ifenthaler, D., \& Schweinbenz, V. (2013). The acceptance of Tablet-PCs in classroom instruction: The teachers' perspectives. Computers in human behavior, 29(3), $525-534$

[30] Venkatesh, V., Thong, J. Y., Chan, F. K., Hu, P. J. H., \& Brown, S. A. (2011). Extending the two-stage information systems continuance model: Incorporating UTAUT predictors and the role of context. Information Systems Journal, 21(6), 527-555.

[31] Affouneh, S., Salha, S., \& Khlaif, Z. N. (2020). Designing Quality E-Learning Environments for Emergency Remote Teaching in Coronavirus Crisis. Med Sci, 11(2), 1-3. 